\title{
A participatory study of teenagers and young adults' views on access and participation in cancer research.
}

Rachel M Taylor PhD, MSc a,b; Anita Solanki , BSc (Hons) ${ }^{a}$; Natasha Aslam, BSc (Hons), $\mathrm{MSc}^{a}$; Jeremy S Whelan , M.Dc.; Lorna Fern, Ph.D, M.Sc ${ }^{d}$

a Cancer Clinical Trials Unit, University College London Hospitals NHS Foundation Trust, 250 Euston Road, London NW1 2PG, United Kingdom

b School of Health and Social Care, London South Bank University, 103 Borough Rd, London SE1 OAA, United Kingdom

c National Institute for Health Research, University College London Hospitals Biomedical Research Centre and Department of Oncology, University College London Hospitals NHS Foundation Trust, 250 Euston Road, London NW1 2PG, United Kingdom

d National Cancer Research Institute, Angel Building, 407 St John Street, London EC1V $4 A D$, United Kingdom

Rachel M Taylor

Cancer Clinical Trials Unit,

University College London Hospitals NHS Foundation Trust, 250 Euston Road,

London NW1 2PG,

United Kingdom

rtaylor13@nhs.net

Anita Solanki

Cancer Clinical Trials Unit,

University College London Hospitals NHS Foundation Trust,

250 Euston Road,

London NW1 2PG,

United Kingdom

Anita.solanki@uclh.nhs.uk

Natasha Aslam

Cancer Clinical Trials Unit,

University College London Hospitals NHS Foundation Trust,

250 Euston Road,

London NW1 2PG,

United Kingdom

natasha.aslam@uclh.nhs.uk

Jeremy Whelan

National Institute for Health Research,

University College London Hospitals Biomedical Research Centre and Department of Oncology,

University College London Hospitals NHS Foundation Trust,

250 Euston Road,

London NW1 2PG,

United Kingdom

Jeremy.whelan@uclh.nhs.uk 
Corresponding author:

Lorna A Fern,

National Cancer Research Institute,

Angel Building,

407 St John Street,

London EC1V 4AD,

United Kingdom

Lorna.fern@cancer.org.uk

\section{ABSTRACT}

\section{Purpose}

Internationally, young people are underrepresented in cancer research and this has been associated with lesser survival. Organisation of care and restrictive eligibility criteria are identified as barriers to recruitment. BRIGHTLIGHT is a National Institute for Health Research study evaluating specialist cancer care for young people aged 13-24 years. Despite broad eligibility criteria and national coverage recruitment is suboptimal. Analysis of screening logs showed that access to BRIGHTLIGHT was being restricted by healthcare professionals who were not offering the opportunity to participate. The purpose of this study was to illicit young people's views on access and participation in cancer research.

\section{Methods}

Eight young people aged 18-25 years with a previous cancer diagnosis aged 15-24 years participated in a one day workshop utilising participatory and qualitative methodology. The workshop consisted of four exercises: role play and scene setting; focus group examining thoughts and opinions of access and participation in research; individual reflection of access to different types of cancer research; creative interpretation of the workshop. Following the workshop further consultation with 222 young people with cancer was carried out using an electronic survey.

\section{Results}

Three themes emerged from the workshop

- Patient choice: Young people thought it was their right to know all options about available research. Without knowledge of all available studies they would be unable to make an informed choice about participation.

- Role of healthcare professionals as facilitators/barriers: Young people suggested non-clinical healthcare professionals such as social workers and youth support coordinators were more suited to approaching young people about participation in psychosocial and health services research.

- Value of the research: The what, when and how information was delivered was key in relaying the value of the study and assisting young people in their decision to participate.

The consultation exercise revealed approximately $70 \%$ wanted to find out about all available research. However, one third trusted healthcare professionals to decide which research studies to inform them of. 


\section{Conclusion}

Effective ways to support healthcare professionals in approaching vulnerable populations about research are needed to ensure young people are empowered to make informed choices about research participation.

Word count: 343

\section{HIGHLIGHTS}

- We examined young people's views on access to and participation in cancer research

- We explored if access to research should be at the discretion of healthcare professionals

- Young people felt it was their human right to be informed of all available research

- Allied healthcare professionals should be involved in recruitment to low risk studies

- Our study supports the concept that young people are willing to take part in research

\section{INTRODUCTION}

The United Kingdom (UK) claims the highest rate of cancer trial participation in the world (Singh 2007). Despite this, there are inequalities in access to research. Patient demographics such as age, socioeconomic status and ethnicity are all recognised as contributing factors (Fern et al. 2008, Fern et al. 2014, Ford et al. 2008, Furlong et al. 2012). Investigations into lower rates of participation for young people with cancer have frequently focused on structural and organisation barriers, lack of available trials and restrictive age eligibility criteria (Fern et al. 2008, Fern et al. 2014, Ford et al. 2008, Furlong et al. 2012). The potential role of 'professional gate-keeping' as a barrier to access to research has received little or no attention.

Young people present with a range of cancer types and exhibit unique psychosocial needs which require specialist age appropriate cancer care. The environment of care is believed to be particularly influential to patient experience but not yet quantified. In August 2005, the National Institute of Health and Care Excellence (NICE) issued Improving Outcomes 
Guidance advocating specialist teenage and young adult (TYA) cancer care delivered in 13 'Principle Treatment Centres' (PTC) (National Institute for Health and Care Excellence 2005). Despite bespoke TYA cancer units and healthcare policy which advocates specialist cancer services for young people, the outcomes and costs associated with such care are yet to be fully described.

Increasing pressure on financial resources together with the UK's position as a leader in providing specialist cancer care for young people has brought the need for an evidence base for specialist services to the forefront. The 'gold standard' - a randomised clinical trial comparing outcomes and costs of specialist care versus non-specialised care is neither ethical nor feasible in a country where implementation and access to TYA services already exist. Following a period of extensive feasibility work, methodology testing and engaging multiple stakeholders including patients (Fern et al. 2013), parents, charitable organisations, TYA, paediatric and adult oncology communities (Gibson et al. 2012, Taylor et al. 2011), National Institute for Health Research (NIHR) Cancer Research Networks and relevant National Cancer Research Institute (NCRI) Clinical Studies Groups, a national study 'BRIGHTLIGHT-Do specialist cancer services for young people add value?' was opened in October 2012.

BRIGHTLIGHT is a longitudinal cohort study evaluating specialist cancer care for young people aged 13-24 years, newly diagnosed with cancer in England (www.brightlightstudy.com). BRIGHTLIGHT aims to determine to what extent specialist cancer care for young people affects outcomes and costs to both young people and the NHS. To ensure maximum recruitment of TYA to the study we developed BRIGHTLIGHT within the context of our five ' $A$ 's conceptual model for increasing participation of young people in cancer research: 'Available, Access, Aware, Appropriate and Acceptable' (Table 1) (Fern et al. 2014). BRIGHTLIGHT is open to recruitment in most NHS Trusts in England thus geographical access is ensured. An age eligibility criterion which spans the TYA age group and broad inclusion criteria also ensure maximum potential for participation. By September 2013, over 400 patients were recruited, making BRIGHTLIGHT the largest cohort of 13-24 year olds with cancer in the world; however this was a quarter of the anticipated recruitment target. An explanation for initial recruitment rates being less than anticipated 
were delays in gaining approval in many Trusts; often BRIGHTLIGHT was being scrutinised with the same regulatory rigour as a Phase I clinical trial. Opening the study in multiple Trusts, including all thirteen PTCs, was not accompanied by significant improvements in recruitment.

Optimising recruitment and facilitating access to research is complex; we engaged with the clinical community and our Young Advisory Panel (YAP) for advice on the lower anticipated recruitment rate. A number of protocol changes were implemented to improve recruitment The protocol amendments, also framed around our five 'As' model were mainly related to improving study awareness, access and acceptability to patients and healthcare professionals (Table 1). However, recruitment rates to the study showed no notable improvements.

Subsequently, screening logs returned from 65 of the 97 open centres were analysed and showed a refusal rate of just $18 \%$ amongst those approached against an anticipated $35 \%$ versus an anticipated 35\% which was based on refusal/consent rates in other published TYA cancer studies (Burns et al., 2009; Carpentier et al., 2008; Kondryn et al., 2009). This high acceptance rate possibly reflects the success of feasibility work to develop BRIGHTLIGHT with young people, for young people, ensuring relevance of study questions and design. Nevertheless, analysis of screening logs also illustrated the main contributing factor for lower than expected accrual was that around a quarter of young people with a new cancer diagnosis were not being approached despite fulfilling the eligibility criteria. Factors such as limited resources were contributory; however, we identified a proportion of patients where healthcare professionals did not feel it was appropriate to approach the patient. Having identified the potential role of 'professional gate-keeping' contributing to lower than anticipated recruitment rates to BRIGHTLIGHT, we sought to elicit young people's views about access to and participation in cancer research.

\section{METHODS}

A qualitative study using participatory methods during a one day workshop in September 2013 was carried out with eight self-selected young people who are part of the 
BRIGHTLIGHT YAP, the study's patient and public involvement representatives. Their remit is to advise on: methodological issues, such as recruitment; create and comment on the content of newsletters and other means of publicising the study; advise on topics for future survey content. They will also be integral in interpreting results and suggesting potential implications and interventions for young adult cancer care.

Information about the day was distributed prior to the workshop, written consent was obtained from workshop participants for audio and visual recording and to use these for multiple purposes, including being placed on the BRIGHTLIGHT website. The workshop was held in a non-clinical office facility. BRIGHTLIGHT is approved by London-Bloomsbury Research Ethics Committee (reference 11/LO/1718).

Four male and four female YAP members attended the workshop, currently aged 18-25 years and who were diagnosed with cancer aged 15-24 years. One young person was still receiving treatment; diagnoses included four haematological malignancies and four solid tumours. Data were collected through role play, focus group, and individual reflection. Four researchers were in attendance at the workshop.

\section{Exercise 1: Role play and scene setting}

The workshop began with role play carried out by four researchers who enacted scenarios illustrating reasons for non-approach, which were outside of the exclusion criteria of the protocol but were cited in the BRIGHTLIGHT screening logs. Additional dialogue reflecting comments that recruiting teams had made were also incorporated into the scenarios. See Table 2 for BRIGHTLIGHT inclusion and exclusion criteria and examples of the scenarios depicted. These included pregnancy, learning disabilities, or the surgeon/doctor did not think participation was appropriate (no other reason supplied).

Exercise 2: Focus group examining thoughts and opinions of access and participation in research

One researcher (LF) led the focus group, which opened with a question to elicit young people's views on the scenarios they had just observed. Discussion within the Group was encouraged with the researcher being reflexive with additional questions. However, there 
were a number of prompts in the discussion guide to ensure all points were covered or discussed.

\section{Exercise 3: Individual reflection of access to different types of cancer research}

Posters of eight types of cancer research with brief definitions were pinned to the wall: improving cancer diagnosis; delivery of care; how to help young people recover more quickly; cancer prevention; new treatments; survivorship and late effects; causes of cancer; and cancer biology in young people. Young people were asked to individually reflect on the focus group discussion on access and participation in research and its relationship to each type of cancer research. Questions on the posters guided young people to reflect on how they would feel if they had not been told about the research, when it would be acceptable not to be told, who was an appropriate person to give them information about the area of research and their opinions on different methods of introducing research, e.g. invitation through the post, adverts on social media. Young people wrote their answers on post-it notes, which were placed on each poster. After individual reflection, as a group we expanded on young people's views about different approaches to being invited to participate in research, focusing on social media invites and where these would be best placed for young people to respond. Posters were left on the wall for the remainder of the day and young people could add too or edit their post it notes.

\section{Exercise 4: Young person-led creative interpretation of the workshop}

The workshop ended with creative audio-visual, young person-led interpretation of the day. Young people worked in two groups, were given video cameras and were asked to creatively interpret the day with emphasis on what they would other young people to know. The research team were not present for this activity.

All data were audio and visually recorded, transcribed verbatim and analysed using thematic analysis.

\section{Post workshop consultation}

Following the workshop we consulted with 222 young people with cancer at a patient conference using an interactive electronic survey as previously described (Smith et al. 2007). 
Young people were asked 'Your treatment team may not tell you about a research study because they do not want to burden you at this team. What are your views on this?' Participants could chose from three predefined answers.

\section{RESULTS}

\section{Exercise 1 and 2: Focus group}

Three main themes emerged from the focus group; see Table 3 for supporting quotes.

Patient choice: Young people thought it was their right to know all their options about what research was available to them. Participants in this group did not feel it was a burden to be approached about research studies, explaining if they had all the information they could then choose to refuse. Without the information they could not make a fully informed choice about their treatment and care.

Role of healthcare professionals as facilitators/barriers: The role of the healthcare professional was perceived as being central to facilitating the decision of whether to participate in research. Young people reported different relationships with members of their multidisciplinary team (MDT) and felt clinically trained professionals, such as doctors and nurses, were paramount to information giving and decisions around drug and treatment research. However, additional team members, such as social workers and youth support coordinators may be more suited to discussing psychosocial and health services research. Young people acknowledged and sympathised with the increasing time pressures for clinical staff and this was recognised as an indirect barrier to recruitment. This further strengthened their rationale for increasing the role of other MDT members, e.g. social workers and youth support coordinators.

Value of the research: The what, when and how of giving information about research studies were all key factors in assisting the choice to participate in research. The way in which information was presented by the person gaining consent was important. For example, if the healthcare professional conveyed the value of the study, the benefit to other young people and were enthusiastic in the delivery of information, young people felt they 
were more likely to participate. Again young people highlighted that other members of the MDT may be more in tune as to when to approach a young person and also convey the value of non-treatment related research.

\section{Exercise 3: Individual reflection}

Young people were asked to comment about access and participation in eight different types of research (Table 4). They all reported being upset if their treatment team withheld study information, and identified the only reasons for not being told about a study was if their physical wellbeing would be affected or "If I was already responding well to current treatment". One young person noted "I think it's always okay to ask people to take part". Table 4 also illustrates their thoughts on being approached about research from different members of their treatment team and responding to adverts on social media. This highlighted differing opinion on the use of social media, with some young people viewing this positively and stating they would use it as a way of involving other young people. Conversely, others felt using social media for recruitment to research was an intrusion of their personal space.

\section{Exercise 4: Creative interpretation}

Young people were asked to creatively interpret the day, which highlighted their views on the importance of BRIGHTLIGHT and the importance of all young people being offered the opportunity to take part (http://www.youtube.com/watch?v=W9HHkE9kEFw\&feature=youtu.be, accessed 17/12/14). The videos also depicted their enthusiasm for user involvement and assisting with study conduct (http://www.youtube.com/watch?v=uHzNfhp80V0, accessed 17/12/14).

\section{Post workshop consultation}

Approximately, seven out of ten young people agreed they wanted to find out about all studies for which they were eligible. However, we have to acknowledge that one third of young people trusted their healthcare professional to decide of which research studies they should be informed (Figure 1).

\section{DISCUSSION}


This is the first study we are aware of which has examined young peoples' views on access, approach and inappropriate professional gate-keeping in cancer research. Among some healthcare professionals approaching vulnerable groups about participation in research is viewed as burdensome to patients (Ford et al. 2008). The opinions of participants in this study to an extent challenged that view as young people saw it as their right to be informed about all research studies for which they were eligible. This is in keeping with the current 'Ok to ask' campaign in the UK which aims to empower patients to ask their treatment team about all research studies available to them (http://www.ct-toolkit.ac.uk/news/its-ok-toask-the-nihrs-new-patient-empowerment-campaign, accessed 17/12/14). It is also in keeping with healthcare policy in the UK: 'no decision about me, without me' (Department of Health 2010).

The NIHR was established in 2006 to provide structure to enhance the conduct, delivery and implementation of research within the NHS. This includes providing over f1billion in funding per year and establishing clinical research networks to facilitate and promote research. Consequently, the UK has the highest participation rate of cancer patients in clinical research in the world (Singh 2007). Despite this substantial investment, many studies still encounter recruitment difficulties (Treweek et al. 2010). In the current climate the economic consequences of poor trial accrual are obvious. Campbell et al. (2007) noted "... if recruitment has to be extended to reach the required sample size, the trial will cost more and take longer, delaying the use of the results in clinical practice. If trials become more expensive and take longer, fewer trials can be conducted overall with the limited funding and resources available."

The research landscape in the UK is changing; limited resources dictate that we must be adaptable and more flexible in our approach to research. Young people recognised the increasing time pressures on clinical staff and advocated that other members of the MDT could explain and consent to non-drug and treatment studies. This is in keeping with the recent Health Research Authority (HRA) report which stated that patients preferred to be told about research by someone knowledgeable about the study irrespective of their 
background (Hunn 2013). How patients seek and use information is also changing, and we should harness the opportunity to use social media and the internet to facilitate patient awareness of research and recruitment to low risk studies.

Healthcare professionals are critical to ensure research success facilitating the link between clinical care and research. However, evidence exists that this facilitator role can also be a barrier to participation (McDonald et al. 2006, Ross et al. 1999), which not only limits access to patients but may also introduce a degree of selection bias. Reasons for over zealous gatekeeping are not entirely understood, but it may be related to a conflict with the healthcare professional role in patient advocacy. This was noted by Grodin and Sassower (1987) 'the principles of beneficence and non-maleficence may compel us to act paternalistically'. This is also linked to quality patient care and the 'first do no harm' principle which underpins current medical practice. Healthcare professionals may think they are protecting their patients from perceived burden; however, they may actually be contributing to unintended harm by restricting patient choice. What healthcare professionals say they do or intend to do, and what happens in practice is not always synonymous. An example of this was shown by Benjamin et al. (2000) who cited that $76-82 \%$ of haematologists said they entered patients into leukaemia clinical trials; however examination of entry rates showed only 36$46 \%$ did so. Similarly, the BRIGHTLIGHT feasibility work with healthcare professionals and the cancer research network uncovered a great deal of enthusiasm for the study yet recruitment rates remain below target.

These findings are subject to a number of limitations. We acknowledge that this is a group of self-selected research-aware young people and may not reflect the views of all young people. They voiced concern on how to reach other young people who were less empowered and knowledgeable than themselves:

'...young people, who are not as proactive... who are not represented here, if you understand what I mean, the less proactive people. So we have to take note of this group of people as well'

However, our results were supported with a larger group of young people with cancer during our consultation and therefore we believe our results to be generalisable particularly for low risk studies such as BRIGHTLIGHT. 


\section{CONCLUSION}

Recent initiatives to increase research activity in the UK cite age and ethnicity as barriers but offer little in the way of solution on how to overcome such barriers (National Cancer Research Institute 2012, http://www.ct-toolkit.ac.uk/news/its-ok-to-ask-the-nihrs-newpatient-empowerment-campaign, accessed 17/12/14). Our previous conceptual model defined 'Access' as critical to improving recruitment rates (Fern et al. 2014); this study supports this and illustrates that access can be blocked through healthcare professional gate-keeping. BRIGHTLIGHT recruitment will cease shortly and recruiting sites will be asked to complete a final screening log and an exit questionnaire. The questionnaire will ask healthcare professionals to bring to mind the last three patients they felt were 'inappropriate to approach' and to describe the reasons why they made that decision and what impact discussing recruitment may have had on the patient. This may allow us to gain some insight as to why paternalistic gatekeeping occurs among some healthcare professionals and identify particular groups of patients that professionals have difficulty in approaching about research. This study highlights the need to find effective ways to support and empower healthcare professionals in approaching vulnerable populations about research; ensuring all potential participants are given transparent information to make an informed choice, improve recruitment rates and ultimately the number of studies reaching completion. 


\section{REFERENCES}

Benjamin, S., Kroll, M.E., Cartwright, R.A., Clough, J.V., Gorst, D.W., Proctor, S.J., Ross, J.R., Taylor, P.R., Wheatley, K., Whittaker, J.A. \& Stiller, C.A., 2000. Haematologists' approaches to the management of adolescents and young adults with acute leukaemia British Journal of Haematology 111, 1045-1050.

Burns DS., Robb SL, Hasse JE., 2009 Exploring the feasibility of a therapeutic music video intervention in adolescent and young adults during stem-cell transplantation. Cancer Nursing, 32, 5: E8-E16

Campbell, M.K., Snowdon, C., Francis, D., Elbourne, D., McDonald, A.M., Knight, R., Entwistle, V., Garcia, J., Roberts, I., Grant, A. \& Grant, A., 2007.Recruitment to randomised trials: strategies for trial enrollment and participation study. The STEPS study. Health Technology Assessment 11, 48

Carpentier MY, Mullins LL, Elkin TD, Wolfe-Christensen C Predictors of health-harming and health-protective behaviors in adolescents with cancer. 2008 Pediatric Blood and Cancer $51,525-530$

Department of Health, 2010. Equity and excellence: Liberating the NHS, The Stationery Office Ltd, UK

Fern, L., Davies, S., Eden, T., Feltbower, R., Grant, R., Hawkins, M., Lewis, I., Loucaides, E., Rowntree, C., Stenning, S. \& Whelan, J., 2008. Rates of inclusion of teenagers and young adults in England into National Cancer Research Network clinical trials: report from the National Cancer Research Institute (NCRI) Teenage and Young Adult Clinical Studies Development Group. British Journal of Cancer 99, 1967-1974

Fern, L., Taylor, R.M., Whelan, J., Pearce, S., Grew, T., Brooman, K., Starkey, C., Millington, H., Ashton, J. \& Gibson, F., 2013. 'The art of age appropriate care': using participatory research to describe young people's experience of cancer. Cancer Nursing 36, E27-E38

Fern, L.A., Lewandowski, J., Coxon, K.M. \& Whelan, J.S., 2014. Available, accessible, aware, appropriate and acceptable: a strategy for improving participation of teenagers and young adults in cancer clinical trials. Lancet Oncology 15, e341-e350.

Ford, J.G., Howerton, M.W., Lai, G.Y., Gary, T.L., Bolen, S., Gibbons, M.C., Tilburt, J., Baffi, C., Tanpitukpongse, T.P., Wilson, R.F., Powe, N.R. \& Bass, E.B., 2008. Barriers to recruiting 
underrepresented populations to cancer clinical trials: a systematic review. Cancer 112 , 228-242.

Furlong, W., Rae, C., Greenberg, M.L. \& Barr, R.D., 2012. Surveillance and survival among adolescents and young adults with cancer in Ontario, Canada. International Journal of Cancer 131, 2660-2667.

Gibson, F., Fern, L., Whelan, J., Pearce, S., Lewis, I.J., Hobin, D. \& Taylor, R.M., 2012. A scoping exercise of favourable characteristics of professionals working in teenage and young adult cancer care: 'thinking outside of the box'. European Journal of Cancer Care 21, 330-339

Grodin, M.A. \& Sassower, R., 1987. Whose patient is this, anyway? IRB 9, 6-7

Hunn, A., 2013. Patient and public engagement project: patient and public dialogue, Health Research Authority, UK.

Kondryn HJ, Edmondson CL, Hill JW, Eden TOB., 2009 Treatment non-adherence in teenage and young adult cancer patients: a preliminary study of patient perceptions. Psychooncology $18,1327-1332$

McDonald, A.M., Knight, R.C., Campbell, M.K., Entwistle, V.A., Grant, A.M., Cook, J.A., Elbourne, D.R., Francis, D., Garcia, J., Roberts, I. \& Snowdon, C., 2006. What influences recruitment to randomised controlled trials? A review of trials funded by two UK funding agencies. Trials 7, 9-9.

National Cancer Research Institute, 2012. Action on Access: widening patient participation in clinical trials. NCRI, UK.

National Institute for Health and Care Excellence, 2005. Guidance on cancer services: improving outcomes in children and young people with cancer. NICE, London.

Ross, S., Grant, A., Counsell, C., Gillespie, W., Russell, I. \& Prescott, R., 1999. Barriers to participation in randomised controlled trials: a systematic review. Journal of Clinical Epidemiology 52, 1143-1156.

Singh, G., 2007. United Kingdom becomes the cancer clinical trials recruitment capital of the world. Journal of the National Cancer Institute 6, 420-422.

Smith, S., Davies, S., Wright, D., Chapman, C. \& Whiteson, M., 2007. The experiences of teenagers and young adults with cancer-results of 2004 conference survey. European Journal of Oncology Nursing 11, 362-368. 
Taylor, R.M., Fern, L., Millington, H., Ashton, J., Grew, T., Brooman, K., Starkey, C., Pearce, S., Whelan, J. \& Gibson, F., 2011. "Your place or mine?" Priorities for a specialist teenage and young adult (TYA) cancer unit: disparity between TYA and professional perceptions. Journal of Adolescent and Young Adult Oncology 1, 145-151.

Treweek, S., Mitchell, E., Pitkethly, M., Cook, J., Kjeldstrøm, M., Johansen, M., Taskila Taina, K., Sullivan, F., Wilson, S., Jackson, C., Jones, R. \& Lockhart, P., 2010. Strategies to improve recruitment to randomised controlled trials. Cochrane Database of Systematic Reviews 4

\section{Funding source:}

This paper presents independent research funded by the National Institute for Health Research (NIHR) under its Programme Grants for Applied Research Programme (Grant Reference Number RP-PG-1209-10013). The views expressed are those of the author(s) and not necessarily those of the NHS, the NIHR or the Department of Health. The BRIGHTLIGHT Team acknowledges the support of the NIHR, through the Cancer Research Network. This study was undertaken at UCLH/UCL who received a proportion of funding from the Department of Health's NIHR Biomedical Research Centres funding scheme. Dr Fern is funded by Teenage Cancer Trust.

\section{Financial disclosure:}

None of the authors have a financial relationship relevant to this article to disclose.

\section{Conflict of interest:}

None of the authors have a conflict of interest to disclose.

\section{Acknowledgements:}

We would like to thank the patients who are participating in BRIGHTLIGHT and the healthcare professionals who are recruiting to the study. We would like to thank the BRIGHTLIGHT Young Advisory Panel (YAP): Laura Haddad, Jason Si Jun Loo, Yaajan Govindia, Stephen Sutton, Kelly Leanne, Freya Voss, Mariia Sanyya and Edward Yelland; the participants of Find Your Sense of Tumour 2013 and the Find Your Sense of Tumour steering committee.

This manuscript is dedicated to the memory of Stephen Sutton, valued member of the National Cancer Research Institutes Teenage and Young Adult Clinical Studies Group and BRIGHTLIGHT YAP.

\section{Contributor's statement:}


Rachel Taylor contributed to the conceptualisation and design of the workshop, was part of the workshop team, assisted in the analysis of transcripts, helped draft the initial manuscript and approved the final manuscript as submitted.

Anita Solanki contributed to the conceptualisation and design of the workshop, was part of the workshop team, assisted in the analysis of transcripts, helped draft the initial manuscript and approved the final manuscript as submitted.

Natasha Aslam was part of the workshop team, assisted in the analysis of transcripts, helped draft the initial manuscript and approved the final manuscript as submitted.

Jeremy Whelan contributed to the conceptualisation of the workshop, helped draft the initial manuscript and approved the final manuscript as submitted.

Lorna Fern contributed to the conceptualisation and design of the workshop, was part of the workshop team, assisted in the analysis of transcripts, helped draft the initial manuscript and approved the final manuscript as submitted. 
Table 1: The five 'A's of BRIGHTLIGHT- optimising young people's participation

\begin{tabular}{|c|c|c|c|}
\hline & Definition of the barriers-promoters ${ }^{1}$ & Addressed in feasibility work and study design & Additional amendments \\
\hline Available & $\begin{array}{l}\text { - } \\
\text { canceasibility of research for rare } \\
\text { - } \\
\text { - } \text { activation of trials in all } \\
\text { appropriate treatment centres } \\
\text { for teenagers and young } \\
\text { adults }\end{array}$ & $\begin{array}{l}\text { - Open to recruitment in as many acute } \\
\text { - Irusts in England as possible } \\
\text { - Inclusive of all cancer types } \\
\text { - Information sheets and consent forms } \\
\text { - Inclusive of young people with learning } \\
\text { disabilities }\end{array}$ & $\begin{array}{l}\text { - Change the recruitment window to increase } \\
\text { the flexibility of when to approach young } \\
\text { people } \\
\text { - Analysis of screening logs (identify regional } \\
\text { variation) }\end{array}$ \\
\hline Accessible & $\begin{array}{ll}\text { - } & \text { Referral to specialist centres; } \\
\text { - } & \text { Collaboration across adult and } \\
& \text { paediatric oncologists }\end{array}$ & $\begin{array}{l}\text { - Open in child, adult and TYA specialist } \\
\text { centres } \\
\text { - Data collection at a time and place } \\
\text { directed by the young person }\end{array}$ & $\begin{array}{l}\text { - } \quad \text { Consent by the BRIGHTLIGHT team (for } \\
\text { young people who contact us direct) } \\
\text { - } \quad \text { Consent by other members of the MDT e.g. } \\
\text { youth support coordinators, social workers } \\
\text { - } \quad \text { Recruitment and consent through the } \\
\text { Twittersphere } \\
\text { Reviewing screening logs to identify } \\
\text { inappropriate reasons for not approaching } \\
\text { young people }\end{array}$ \\
\hline Aware & $\begin{array}{l}\text { - Health-care professionals' } \\
\text { - } \quad \text { awareness of trials; } \\
\text { teenareness of need to offer } \\
\text { trial entry; increased patient } \\
\text { awareness; } \\
\text { - increased paediatric and } \\
\text { adult communication }\end{array}$ & $\begin{array}{l}\text { - Feasibility work involved key stakeholders } \\
\text { (patient, professional, policy and } \\
\text { charities) } \\
\text { - National and local presentations about } \\
\text { the study } \\
\text { - Website with participant and healthcare } \\
\text { - } \text { professional sections } \\
\text { - Weekly update circulated in the } \\
\text { professional society news bulletin }\end{array}$ & $\begin{array}{l}\text { - } \\
\text { - } \quad \text { Newsletters updating about the study } \\
\text { - } \quad \text { Information distributed at a national patient } \\
\text { conference } \\
\text { - } \quad \text { Promotional adverts included in a national } \\
\text { conference newsletter } \\
\text { - } \quad \text { Information distributed by national cancer } \\
\text { - } \quad \text { Presentations to senior nurses } \\
\text { - } \quad \text { Emails from the Director/Assistant Directors } \\
\text { - } \quad \text { Article about the study included in a }\end{array}$ \\
\hline
\end{tabular}




\begin{tabular}{|c|c|c|c|}
\hline & & & $\begin{array}{l}\text { national newspaper } \\
\text { - Information included in a national television } \\
\text { news item }\end{array}$ \\
\hline Appropriate & $\begin{array}{l}\text { - } \\
\text { dddressed during study } \\
\text { development. Ensure age } \\
\text { restrictions on trials are } \\
\text { appropriate to cancer type } \\
\text { and research question }\end{array}$ & $\begin{array}{l}\text { Age eligibility inclusive of TYA (13-24 } \\
\text { years) which addresses the research } \\
\text { question. }\end{array}$ & - No amendment required \\
\hline
\end{tabular}

${ }^{1}$ Fern et al (2014) reproduced with permission

TYA: teenage and young adult; NCRI CSG: National Cancer Research Institute Clinical Studies Group; NCRN: National Institute for Health Research Cancer Research Network 
Table 2: $\quad$ Eligibility criteria for BRIGHTLIGHT and examples of role play scenarios based on reasons presented in screening logs for not approaching young people

\begin{tabular}{|l|l|}
\hline Eligibility criteria \\
\hline Inclusion: & Exclusion: \\
- Diagnosed with cancer within the last four months & $-\quad$ Not capable of completing the survey \\
- Aged $13-24$ at the time of diagnosis & $-\quad$ Does not consent or assent \\
- Resident in England at the time of diagnosis & $-\quad$ Recurrence of previous cancer \\
& $-\quad$ Death is imminent \\
& $-\quad$ Receiving a custodial sentence at time of \\
& treatment
\end{tabular}

\section{Scenarios}

Researcher: Nurse, please can you talk to Jamil about BRIGHTLIGHT, find out if he wants to take part? Really? There's no point, he doesn't speak or read English. And anyway, I haven't seen him for a Nurse: $\quad$ bit. I think he's gone outside or something.

Doctor James, is it possible to talk to Samuel about BRIGHTLIGHT?

Researcher: $\quad M m m m$, he's a bit upset at the moment so I don't think it's really appropriate.

Doctor: I just wanted to follow-up about Samuel, it's been a couple of months since I spoke to you Researcher: about approaching him for BRIGHTLIGHT.

Sorry, I just don't think it's appropriate that he's approached.

Doctor: What do you mean? He is still within the study time frame, he's not dying and he's not in Researcher: prison. Look, I understand this study is important to you but I'm quite busy and I'm telling you it's not Doctor: appropriate that you talk to him about this study.

Nurse, is it possible to talk to Jasminder to take part in BRIGHTLIGHT?

Researcher: Jasminder has Down syndrome and learning disabilities; I don't think she's going to be able to Nurse: $\quad$ complete a survey.

Our interviewers are skilled in communicating with people with mild to moderate learning

Researcher: difficulties, are you sure she can't take part?

I'm sorry. I really don't think so. She's not going to be able to say very much about her

Nurse: experience anyway. Maybe you can find someone else to approach who is more suitable.

Table 3: Supporting quotes for themes emerging from the workshop

\begin{tabular}{|l|l|}
\hline Theme & Supporting quotes \\
\hline Patient choice & $\begin{array}{l}\text { "If you can get asked you can just say no." } \\
\text { "...if you let them [patients] know what the impact it is going to have and give them the } \\
\text { choice so it's at the back of their head, they know when they have the strength they can } \\
\text { call and say they want to do the first part, take it from" } \\
\text { "You should have the right to partake in studies so long as they don't physically clash.... is } \\
\text { currently on two drug trials." } \\
\text { "But as long as the patient wants to do it, it is fine." }\end{array}$ \\
\hline
\end{tabular}




\begin{tabular}{|c|c|}
\hline & $\begin{array}{l}\text { "At the end of the day it is your decision isn't it? If they give you the option it is up to you } \\
\text { to say yes or no. At the end of the day I know they are treating me and they are trying to } \\
\text { help me get better but at the end of the day you know how you are feeling inside. Ok you } \\
\text { might not look it but you know. I have had days when I have looked awful but I feel good } \\
\text { on the inside and I have been able to talk to people for a while. If they at least tell you } \\
\text { about it and you can be more aware of it. Personally it would make me feel like I'm more } \\
\text { important like I am not just a patient I am actually a person and they want me to help other } \\
\text { people as well." }\end{array}$ \\
\hline $\begin{array}{l}\text { Role of healthcare } \\
\text { professionals as } \\
\text { facilitators/barriers }\end{array}$ & $\begin{array}{l}\text { "From what I can see the problem doesn't lie with the young adult, it lies purely with the } \\
\text { health professionals. The reason being why they are acting this way is because they don't } \\
\text { see the value of the survey." } \\
\text { "I think it is also twofold the reasons why nurses and doctors don't want to do it is because } \\
\text { they don't understand the value and also because like they might be quite busy and so they } \\
\text { just don't want to take on any extra work. It would be better just to brush you off because } \\
\text { then they don't have to deal with it, they don't have to take responsibility of speaking to } \\
\text { the patient" } \\
\text { "I think the route of going through the social worker is much more effective because you } \\
\text { are no longer restricted to the traditional route of the doctors and healthcare } \\
\text { professionals." } \\
\text { "Maybe it makes more sense for the youth worker to do it because you are more likely to } \\
\text { talk to them about the experience of being treated." } \\
\text { "...the better route would be through the social workers. Because my experience is that } \\
\text { health professionals have to have professional conduct, they can't be too personal with } \\
\text { you because they have to protect themselves as well. Whereas the social worker" }\end{array}$ \\
\hline Value of research & $\begin{array}{l}\text { "If they were able to see the value of the survey... what kind of outcome and impact this } \\
\text { survey would have for patients then they would be very proactive about it, because I think } \\
\text { when I participated in the BRIGHTLIGHT survey when I was interviewed my healthcare } \\
\text { professional was quite proactive about it. She sees the value or the survey" } \\
\text { "If you are able to convey a very good message, if you can send a good message across, this } \\
\text { survey is going to give this kind of impact and this outcome, and what kind of impact this } \\
\text { will give to their patients. Because I'm sure the healthcare professionals want the best for } \\
\text { their patients. If they are able, make them see the value then the message will be } \\
\text { smoother and it will come across easier." } \\
\text { "I think the patient has to get something out of it. Because they are making the investment } \\
\text { of their time they will want something out of it." }\end{array}$ \\
\hline
\end{tabular}


Table 4:

Young people's perceptions of access to different areas of research

\begin{tabular}{|c|c|c|c|c|c|}
\hline Study type & $\begin{array}{l}\text { If I found out my treatment } \\
\text { team had withheld a study } \\
\text { I would feel... }\end{array}$ & $\begin{array}{l}\text { Its okay for my treatment } \\
\text { team not to tell me if... }\end{array}$ & $\begin{array}{l}\text { It's okay for someone } \\
\text { other than my doctor or } \\
\text { nurse to talk to me about } \\
\text { this... }\end{array}$ & $\begin{array}{l}\text { If I received study } \\
\text { information in the post I } \\
\text { would... }\end{array}$ & $\begin{array}{l}\text { If I saw an advert on social } \\
\text { media I would... }\end{array}$ \\
\hline $\begin{array}{l}\text { Improving cancer } \\
\text { diagnosis }\end{array}$ & $\begin{array}{l}\text { "Upset as I would like to } \\
\text { help raise awareness" } \\
\text { "Annoyed as I know many } \\
\text { people who have had } \\
\text { diagnosis problems and } \\
\text { don't want it to happen to } \\
\text { others" }\end{array}$ & $\begin{array}{l}\text { "I was too unwell to take } \\
\text { part" }\end{array}$ & $\begin{array}{l}\text { "Yes as it is about raising } \\
\text { awareness so can get more } \\
\text { info from social workers" }\end{array}$ & $\begin{array}{l}\text { "Want to take part. } \\
\text { However, if I am in the } \\
\text { middle of my treatment I } \\
\text { may not feel well enough } \\
\text { to take care of the postage } \\
\text { myself" }\end{array}$ & $\begin{array}{l}\text { "Be up for taking part!" } \\
\text { "Not be so inclined to take } \\
\text { part. Twitter and Facebook } \\
\text { are impersonal/informal to } \\
\text { me. Face to face approach } \\
\text { and letters in the post } \\
\text { would feel more important } \\
\text { and valid" }\end{array}$ \\
\hline Delivery of care & $\begin{array}{l}\text { "My chances of survival } \\
\text { may have been } \\
\text { compromised" } \\
\text { "Disappointed" } \\
\text { "Upset as it may have } \\
\text { improved my emotional } \\
\text { outlook during treatment" } \\
\text { "Disappointed with health } \\
\text { professionals" }\end{array}$ & $\begin{array}{l}\text { "I'm like properly ill and } \\
\text { they know I'll get annoyed } \\
\text { getting asked" }\end{array}$ & "Agree" & $\begin{array}{l}\text { "Take part if I'm not already } \\
\text { too busy with other } \\
\text { studies" } \\
\text { "Probably (to be honest) } \\
\text { not take much notice unless } \\
\text { someone contacted me } \\
\text { personally/directly" }\end{array}$ & $\begin{array}{l}\text { "Depends on advert" } \\
\text { "Take part if I see many } \\
\text { young people who are } \\
\text { already part of the survey/if } \\
\text { my friends have already } \\
\text { liked the page" } \\
\text { "Take notice if it seemed } \\
\text { interesting (make it } \\
\text { swaggy)" }\end{array}$ \\
\hline $\begin{array}{l}\text { How to help young } \\
\text { people recover more } \\
\text { quickly }\end{array}$ & $\begin{array}{l}\text { "Taking part in a study like } \\
\text { this, and being and feeling } \\
\text { relevant, is crucial for } \\
\text { mental recovery" } \\
\text { "Meeting others going } \\
\text { through similar } \\
\text { experiences" }\end{array}$ & "I was unlikely to recover" & "I would prefer this" & $\begin{array}{l}\text { "Feel like I've been invited } \\
\text { as a person not a patient } \\
\text { who just happened to fit } \\
\text { the criteria" }\end{array}$ & $\begin{array}{l}\text { "I would take part if } \\
\text { contacted on Facebook \& } \\
\text { Twitter rather than } \\
\text { professionals or social } \\
\text { workers. I wouldn't feel } \\
\text { pressured." } \\
\text { "Would be likely to } \\
\text { respond" }\end{array}$ \\
\hline
\end{tabular}




\begin{tabular}{|c|c|c|c|c|c|}
\hline & & & & & $\begin{array}{l}\text { "I'd be encouraged to alert } \\
\text { and share this study with } \\
\text { my other friends who also } \\
\text { have cancer. Something we } \\
\text { can do together." }\end{array}$ \\
\hline $\begin{array}{l}\text { Preventing cancer in } \\
\text { young people }\end{array}$ & $\begin{array}{l}\text { "Upset that I would have } \\
\text { wanted to taken (sic) part" }\end{array}$ & $\begin{array}{l}\text { "If affect my health, if I was } \\
\text { to (sic) weak/tired to take } \\
\text { part" }\end{array}$ & $\begin{array}{l}\text { "No, I would want more } \\
\text { medical information } \\
\text { provided by Dr or nurse } \\
\text { specialist" } \\
\text { "Yes social worker or TCT } \\
\text { activity coordinator" }\end{array}$ & $\begin{array}{l}\text { "If it was detailed and there } \\
\text { was an incentive to take } \\
\text { part, then yes" }\end{array}$ & $\begin{array}{l}\text { "This would promote the } \\
\text { study more. Seriously who } \\
\text { hasn't got it?" } \\
\text { "Would be likely to } \\
\text { respond" } \\
\text { "Maybe, it would have to } \\
\text { be detailed and contact } \\
\text { available" }\end{array}$ \\
\hline New treatments & $\begin{array}{l}\text { "Violated" } \\
\text { "Upset because it may have } \\
\text { offered a better option of } \\
\text { treatment that is more } \\
\text { effective" }\end{array}$ & $\begin{array}{l}\text { "If I am already responding } \\
\text { well to current treatment } \\
\text { and wouldn't want to put } \\
\text { me at risk when } \\
\text { unnecessary" }\end{array}$ & & $\begin{array}{l}\text { "If I was posted a letter to } \\
\text { take part in a study I might } \\
\text { not be as pro-active in } \\
\text { replying and sending back. } \\
\text { But an email is more } \\
\text { accessible for me, and my } \\
\text { youth worker presenting it } \\
\text { tome will be more } \\
\text { effective" } \\
\text { "Want to find out more. } \\
\text { Preferably from a } \\
\text { discussion with an actual } \\
\text { person" }\end{array}$ & $\begin{array}{l}\text { "Not think it was very } \\
\text { trustworthy as it is too } \\
\text { clinical \& I'd worry that } \\
\text { they didn't have the right } \\
\text { info about me" }\end{array}$ \\
\hline $\begin{array}{l}\text { Survivorship and late } \\
\text { effects }\end{array}$ & $\begin{array}{l}\text { "Proper mad ting (sic)" } \\
\text { "Disappointed not to make } \\
\text { my own mind up because I } \\
\text { believe strongly in the } \\
\text { importance of research. I }\end{array}$ & $\begin{array}{l}\text { "Upset as I would want to } \\
\text { be aware of late effects so I } \\
\text { could monitor and control } \\
\text { them" } \\
\text { "I think its always okay to }\end{array}$ & & & $\begin{array}{l}\text { "Be up for taking part" } \\
\text { "Yes because I would be } \\
\text { ready to help and give my } \\
\text { experience" }\end{array}$ \\
\hline
\end{tabular}




\begin{tabular}{|c|c|c|c|c|c|}
\hline & $\begin{array}{l}\text { don't think I would feel } \\
\text { annoyed at the treatment } \\
\text { team if they had my best } \\
\text { interests at heart." }\end{array}$ & ask people to take part" & & & \\
\hline Causes of cancer & & $\begin{array}{l}\text { "If I was undergoing a lot of } \\
\text { invasive procedures as it } \\
\text { was and if I was not } \\
\text { emotionally ready for } \\
\text { more" }\end{array}$ & $\begin{array}{l}\text { "No as it is more clinical } \\
\text { and would want more info } \\
\text { from a healthcare } \\
\text { professional" }\end{array}$ & & $\begin{array}{l}\text { "Probably not if I was still } \\
\text { on treatment or was } \\
\text { unfamiliar with the } \\
\text { company as FB \& Twitter } \\
\text { are very informal" }\end{array}$ \\
\hline $\begin{array}{l}\text { Cancer biology in } \\
\text { young people }\end{array}$ & $\begin{array}{l}\text { "Upset as it may have } \\
\text { helped improve my } \\
\text { treatment and it's my } \\
\text { choice" }\end{array}$ & $\begin{array}{l}\text { "Yes if it effected my well- } \\
\text { being or health in any way" }\end{array}$ & $\begin{array}{l}\text { "Maybe but probably better } \\
\text { from medical team as they } \\
\text { probably deal with older } \\
\text { people too" }\end{array}$ & $\begin{array}{l}\text { "Be less likely to respond by } \\
\text { post esp (sic) if unwell and } \\
\text { unwilling to go outside!" }\end{array}$ & \\
\hline
\end{tabular}

Figure 1 
Your treatment team may not tell you about a research study as they do not want to burden you at this time. What are your views on this?

1. I should be told about all research studies so I can decide $68 \%$

2. I trust my treatment team to make these decisions for me $28 \%$

3. I am not a cancer patient $4 \%$ 
